\title{
KAJIAN IKONOGRAFI MOTIF MEGA MENDUNG CIREBON
}

\author{
Irwan Maolana Yusup \\ Program Studi Desain Komunikasi Visual \\ Fakultas Bahasa dan Seni \\ Universitas Indraprasta PGRI \\ Email: irwanmaulanayusup@gmail.com
}

\begin{abstract}
Diterima : 1 Agustus 2020. Disetujui : 15 November 2020. Dipublikasikan : 1 Desember 2020 (c) (7) 02020 - DESKOVI Universitas Maarif Hasyim Latif. Ini adalah artikel dengan akses terbuka di bawah lisensi CC BY 4.0 (https://creativecommons.org/licenses/by/4.0/)
\end{abstract}

\begin{abstract}
ABSTRAK
Hasil penelitian ini berisi deskripsi pra ikonografi yang menerangkan pada tahap awal aspek ide tekstual, yaitu berdasarkan analisis unsur-unsur visual pada motif mega mendung ini termasuk dengan gaya ketepatan objektif, selain itu juga ditinjau dari motifnya mega mendung menggunakan gaya stilisasi yaitu dengan merubah bentuk asli dari suatu sumber menjadi bentuk yang baru yang bersifat dekoratif tetapi dari ciri khusus dari sumber tersebut tidak hilang sepenuhnya. Tema dan konsep yang terungkap dalam motif mega mendung ini mendapat ide yang diadopsi dari keramik-keramik Cina atau pernak pernik yang dibawa oleh putri Ong Tien, pernak pernik yang dibawa dari cina kemudian dikombinasikan dengan kebudayaan khas Cirebon, sehingga menghasilkan perpaduan kebudayaan Cirebon-Cina. Dari pengaruh budaya tersebut motif mega mendung memiliki ciri khas dan makna yang sangat mendalam sebagai hasil dari interaksi sosial dan masyarakat.
\end{abstract}

Kata kunci: Motif Mega Mendung Cirebon

\begin{abstract}
The Results from this study contains a description of the pre iconography which explaining at an early stage aspects of textual ideas, elements in this mega mendung's motif, including the style of objective accuracy, besides that, also viewed from mega's motive using stylization style that is by changing the original form of a source into a new form which is then added to the special characteristics of the source did not disappear completely. The theme and concept revealed in this mega mendung's motive got an idea adopted from Chinese ceramics or knick knacks which brought by Ong Tien's Princess. Knick knacks which brought from China were then combined with Cirebon culture, resulting in a fusion of Cirebon-Chinese culture. From these cultural influences, mega mendung's motive have very deep characteristics and meanings as a result of social and community interaction.
\end{abstract}

Keywords: Mega Mendung's Motive of Cirebon

\section{PENDAHULUAN}

Batik merupakan salah satu karya seni Bangsa Indonesia yang sudah diakui oleh dunia Internasional dan merupakan unsur identitas budaya Nasional Indonesia. berdasarkan perwujudannya. Salah satu daerah yang memiliki ciri khas dari batiknya adalah Cirebon. Karmila (2010: 26) menyebutkan dalam Batik Cirebon memiliki dua corak utama yaitu batik Keratonan dan juga batik Pesisiran. Motif keratonan ini karena di Cirebon memiliki tiga buah keraton yaitu keraton Kasepuhan, keraton Kanoman, dan keraton Kacirebonan. Motif Keratonan biasanya menggunakan bentuk yang diambil dari lingkungan keraton, seperti Taman Arum Sunyaragi, Singa Barong, Naga Seba, Ayam Alas, dan Wadasan. Motif pesisiran memiliki ciri gambar lebih bebas melambangkan masyarakat Pesisir seperti gambar aktivitas masyarakat di pedesaan, gambar awan-awanan, flora dan fauna seperti gambar dedaunan, pohon, dan binatang laut.

Yudhoyono (2010:41) menyebutkan bahwa sekian banyak motif batik yang ada di Cirebon, motif awan-awanan atau Mega Mendung adalah salah satu motif batik khas Cirebon.

Mega Mendung mendapat pengaruh dari Cina karena peranan Sunan Gunung Jati yang menikah dengan putri Cina bernama Ong Tien. Putri Ong Tien sangat menyukai kesenian, sehingga motif-motif pada keramik yang dibawa dari Cina ini akhirnya mempengaruhi motif-motif batik Cirebon. Motif-motif pada keramik yang dibawa dari negeri Cina ini akhirnya mempengaruhi motif-motif batik sehingga terjadi perpaduan antara kebudayaan Cirebon-Cina (Hamidin, 2010:41). Mega Mendung ini memiliki 
warna gradasi dari biru tua sampai biru muda yang kadang-kadang mencapai 9 sampai 11 nuansa (Djoemena, 1990:38).

Menurut Prasetyo (2010: 59) gradasi warna pada Mega Mendung ini merupakan pengaruh budaya dari Cina. Warna pada Mega Mendung mendapat pengaruh dari keramik biru putih. Menurut Rasjoyo (2008:12) menyebutkan bahwa warna yang mencolok tersebut mendapat pengaruh dari warna keramik pada masa Dinasti Ming. Menurut filsafat Cina 5 kuno. Mega Mendung ini telah ada sejak jaman dahulu sekitar abad ke 14 dan hanya digunakan oleh kalangan keraton saja. Seiring dengan perkembangan Mega Mendung sekitar tahun 1980an, Mega Mendung kini dapat digunakan oleh berbagai kalangan. Motif dan warnanya pun hanya terikat pada motif awan-awanan yang menggumpal dengan menggunakan warna merah dan gradasi biru. sehingga warna Mega Mendung lebih atraktif dengan menggunakan banyak warna yang cerah dan kontras.

Dari hasil penjelasan di atas pertumbuhan dan perkembangan batik Cirebon yang memiliki kedua klasifikasi yaitu batik pesisiran dan batik keratonan adalah bukti betapa uniknya batik Cirebon tersebut. Dari beberapa motif di Cirebon yang memiliki motif yang amat dekat dengan batik Mega Mendung pada awal perkembangan jika ditinjau dari segi visual, disamping itu motif Mega Mendung memiliki tingkat kerumitan yang lebih jika dibandingkan dengan motif batik yang lainnya. Hal ini yang membuat motif Mega Mendung menarik untuk diteliti dengan melihat sejarah munculnya motif tersebut.

Berdasarkan latar belakang tersebut, maka dapat ditarik rumusan masalah sebagai berikut: Bentuk tekstual apa saja yang terdapat pada motif Mega Mendung serta apa dan bagaimana keadaan pada zaman tersebut sehingga terbangun tampilan visual atau motif pada kain batik tersebut, serta apa saja nilai simbolik yang terdapat pada kain batik motif Mega Mendung tersebut?

Untuk menjawab permasalahan-permasalahan tersebut menggunakan landasan teori ikonologi dan ikonografi dari Erwin Panofsky. Sebagai pisau bedah untuk menganalisis motif mega mendung Cirebon kajian Ikonografi menurut Panofsky merupakan metode interpretasi karya seni yang digunakan untuk mengungkap makna bertingkat. Selanjutnya Panofsky berpendapat bahwa pendekatan sejarah merupakan salah satu cara untuk meneliti dan memahami karya seni. Panofsky membagi tiga tahapan untuk menganalisis karya seni yakni tahap pra-ikonografi, ikonografi dan ikonologi. Panofsky menitik beratkan teori tersebut bukan pada bentuk karya melainkan isi dalan sebuah karya. Maka penginterpretasian karya melalui tahap analisis tekstual, tema dan konsep, dan analisis makna secara ikonologi. Dari tiga tahapan tersebut terbagi saling berkesinambungan dan memiliki alat interpretasi dan prinsip korektif masing-masing. Tiga tahapan pendekatan ikonografi menurut Panofsky: (Panofsky, 1955: 39-40).

\begin{tabular}{|l|l|}
\hline Objek interpretasi & Aksi interpretasi \\
\hline $\begin{array}{l}\text { Pokok bahasan primer. A. } \\
\text { Faktual, B.Ekspresional, } \\
\text { menyusun dunia motif } \\
\text { artistik. }\end{array}$ & $\begin{array}{l}\text { Deskrpsi } \\
\text { ikonografi }\end{array}$ \\
\hline $\begin{array}{l}\text { Pokok bahasa sekunder } \\
\text { atau konvensional, } \\
\text { menyusun dunia gambar, } \\
\text { carita dan alegori. }\end{array}$ & Analisis ikonogarfi \\
\hline $\begin{array}{l}\text { Makna intrinsik atau isi } \\
\text { yang menyusun dunia } \\
\text { symbol }\end{array}$ & Interpretasi ikonologi \\
\hline
\end{tabular}

Tabel 1. Tiga tahapan pendekatan ikonografi menurut Panofsky

Untuk mempertajam analisis dalam pendekatan ini panofsky juga menyebutkan prinsip korektif dan interpretasi setiap proses yang mendukung telaah setiap proses mengkaji sebuah karya seni. Hal ini juga sebagai pembuktian akan fakta-fakta atau fenomena yang ingin diungkapkan dalam menelaah karya seni. Tingkatan tahap tersebut seperti tabel di bawah ini.

\begin{tabular}{|c|c|}
\hline Alat interpretasi & $\begin{array}{l}\text { Prinsip korektif dari } \\
\text { interpretasi }\end{array}$ \\
\hline $\begin{array}{l}\text { Pengalaman praktis (rasa } \\
\text { familiar dari objek } \\
\text { perstiwa) }\end{array}$ & $\begin{array}{l}\text { Sejarah gaya, mencari } \\
\text { objek peristiwa yang } \\
\text { dinyatakan alam bentuk. }\end{array}$ \\
\hline $\begin{array}{l}\text { Pengetahuan tentang } \\
\text { sumber literatur (rasa } \\
\text { familiar akan tema dan } \\
\text { konsep) }\end{array}$ & $\begin{array}{l}\text { Sejarah tipe, mencari } \\
\text { tema dan konsep khusus } \\
\text { melalui peristiwa- } \\
\text { peristiwa, }\end{array}$ \\
\hline $\begin{array}{l}\text { Institusi sintetis } \text { (rasa } \\
\text { familiar dengan tendensi } \\
\text { pikiran manusia) } \\
\text { dikondisikan oleh } \\
\text { psikologi personal dan } \\
\text { pandangan hidup. }\end{array}$ & 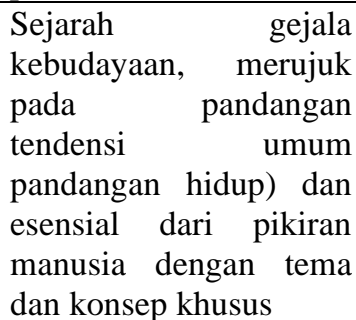 \\
\hline
\end{tabular}

Tabel 2. Alat interpretasi dan prinsip korektif dari interpretasi

\section{METODE PENELITIAN}

Metode penelitian ini menggunakan metode kualitatif. Langkah pertama dalam penelitian ini adalah pencarian sumber-sumber data. Pencarian sumber data itu dilaksanakan dilapangan, pendokumentasian dilingkungan keraton dan narasumber pelaku sejarah sebagai bahan data penelitian. Langkah kedua adalah analisis dan interpretasi sumber-sumber data yang digunakan untuk menghasilkan sintesis. Pembahasan batik mega mendung di analisis dengan metode ikonografi-ikonologi. Seperti yang dinyatakan oleh 
Erwin Panofsky (1955:28-31) bahwa metode ikonografi dikerjakan melalui tiga tahapan yaitu:

1. Pra-ikonografi

Pada tahapan ini interpretasi berfokus pada pokok bahasan alami karya yang dilihat dari sisi faktual maupun ekspresional kemudian pokok bahasan tersebut menyusun dunia motif artistik.Tahap ini merupakan tahap awal atau tahap tekstual dimana pengidentifikasian objek dan peristiwa direpresentasikan melalui garis, warna, dan volume yang menyusun dunia motif (Panofsky, 1955: 33). Pemahaman konteks visual dari sebuah karya seni, dilakukan dengan menghubungkan pengalaman praktis peneliti ke dalam prinsip korektif yang disebut dengan sejarah gaya/style.

\section{Ikonografi}

Tahapan analisis ikonografi dilakukan untuk mengidentifikasi makna sekunder yang terdapat di dalam karya seni tersebut.Makna skunder mengacu pada dunia imaji, cerita dan alegori. Dalam tahap ini, proses analisis dilakukan dengan mengkonfirmasikan obyek yang dikaji dengan menggunakan ilmu bantu seperti kajian literatur yang berisi keterbiasaan dengan tema dan konsep yang spesifik. Dari analisis tersebut akan diketahui bagaimana isi cerita dan sumber ide dari obyek yang dikaji.

3. Ikonologi

Tahapan ini menjadi penting mengingat fungsinya sebagai tahap untuk mengetahui isi sebenarnya dari sebuah karya seni. Kemampuan intuisi sintesis yang menyangkut tendensi esensial pemikiran psikologi personal dan pandangan hidup pencipta karya diperlukan untuk mengidentifikasi makna intrinsik karya (Panofsky, 1955:41).

Teori bantu yang diperlukan untuk mengartikan simbol-simbol yang terdapat dalam unsurunsur visual pada Motif Mega mendung adalah teori Herbert Blumer. Pada teori ini dijelaskan bahwa simbol menunjuk kepada sifat khas dari interaksi antar manusia, dimana manusia saling menerjemahkan dan saling mendefinisikan simbol-simbol yang disajikan oleh orang lain.

\section{HASIL DAN PEMBAHASAN}

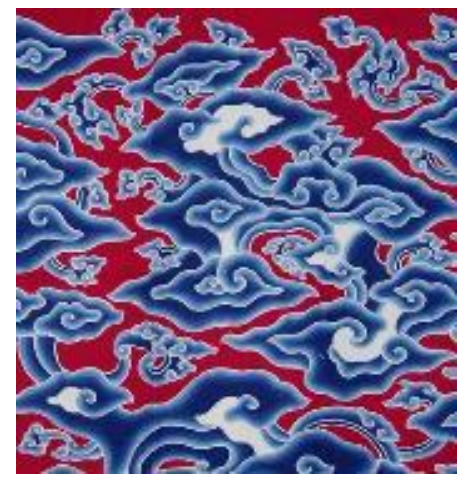

Gambar 1. Motif mega mendung Sumber: katalog batik khas jawa barat (1996: 2)

\section{Analisis Tahap Pra-Ikonografi Batik Mega Mendung Cirebon}

Pada tahapan pra-ikonografi analisis yang dilakukan hanya berkisar pada aspek tekstual dalam karya seni, yang kemudian selanjutnya ditinjau melalui prinsip korektif sejarah gaya. Dalam mencermati setiap aspek yang terdapat pada motif Mega Mendung dapat digunakan pernyataan dari Edmund B. Feldman ( 1967: 164-166) yang menyatakan bahwa garis, bentuk, warna, tekstur, serta gelap dan terang merupakan bagian-bagian dari wujud gambar yang dikarakteristikkan, memberikan sebuah label yang kemudian mengarahkannya dengan makna.

Berdasarkan analisis unsur-unsur visual pada motif Mega Mendung dapat dikatakan memiliki kecenderungan terhadap gaya ketepatan objektif. Sesuai dengan teori Feldman (1967: 6) yang menyatakan karya dengan gaya ketepatan objektif merupakan karya yang memiliki hubungan yang erat dengan tiruan tentang fenomena visual. Motif-motif yang terdapat pada karya tersebut tidak mengejar kepada bentuk-bentuk ideal seperti karya realis, akan tetapi batik pada motif Mega Mendung ini lebih mengutamakan terhadap peniruan wujud dari fenomena atau apa yang seniman tangkap dengan panca indra mereka yang merupakan bagian dari proses untuk mencapai penyesuaian dengan dunia yang sebenarnya.

Selain itu jika ditinjau dari motifnya, Mega Mendung menggunakan gaya stilisasi. Dimana gaya tersebut digambarkan dengan menyususn motif baru dengan merangkai bentuk yang salah kemudian disederhanakan, atau merubah bentuk asli dari suatu sumber menjadi bentuk yang baru yang bersifat dekoratif tetapi ciri khusus dari sumber tersebut tidak hilang sepenuhnya.

Prinsip korektif pada tahap pra-ikonografi ini dapat dilihat bagaimana karya-karya batik Mega Mendung pada zaman tersebut yang berkaitan erat dengan proses asimilasi atau pertukaran budaya serta tradisi religius yang terjadi di Cirebon. Hal tersebut terjadi sejak Sunan Gunung Jati menyebarkan agama islam di Cirebon pada abad ke-16 sejarah batik Cirebon berawal ketika pelabuhan Muara Jati, yang kini disebut pelabuhan Cirebon, dijadikan tempat persinggahan pada pedagang asing. Sebagian besar pedagang asing tersebut berasal dari Tiongkok, Arab, Persia, dan India. Masuknya para pedagang asing ini kemudian menciptakan asimilasi dan akulturasi dari beragam budaya yang menghasilkan banyak tradisi baru, salah satunya adalah batik Cirebon. Tidak hanya motif dalam kain, terdapat motif Mega Mendung yang digunakan pada arsitek keraton di Cirebon.

Motif Mega Mendung identik dan bahkan menjadi ikon batik pesisir Cirebon. Kekhasan Mega Mendung atau "awan-awanan" tidak saja pada motifnya yang berupa gambar menyerupai awan dengan warna-warna tegas seperti biru dan merah, tetapi juga pada nilai-nilai filosofi yang terkandung pada motifnya. Hal ini sangat berkaitan dengan casta (sejarah lahirnya batik scara keseluruhan di Cirebon. 
Menurut Casta (2009: 30) menuturkan bahwa sejarah batik dimulai ketika pelabuhan Muara Jati atau Cirebon menjadi tempat persinggahan pedagang Tiongkok, Arab, Persia, dan India. Saat itu terjadi asimilasi dan akulturasi dari beragam budaya yang menghasilkan banyak tradisi baru bagi masyarakat Cirebon.

Pernikahan putri Ong Tien dan Sunan Gunung Jati merupakan latar belakang masuknya budaya dan tradisi Tiongkok atau tradisi Cina ke keraton. Pada saat itu, keraton menjadi pusat kosmologi sehingga ide tau gagasan pernak pernik tradisi dan budaya Cina yang masuk bersama putri Ong Tien menjadi pusat perhatian para seniman di Cirebon. Sedangkan pernak-pernik Cina yang dibawa putri Ong Tien sebagai persembahan kapada Sunan Gunung Jati, menjadi inspirasi seniman termasuk pembatik.

Motif Cina ini hanya sebagai inspirasi. Seniman batik Cirebon kemudian mengolahnya dengan cita rasa masyarakat setempat yang mayoritas beragama islam. Dari situ, lahirlah motif batik dengan ragam hias dan keunikan khas tersendiri.

\section{Analisis Tahap Ikonografi Batik Mega Mendung Cirebon}

Pembahasan pada tahapan ini diarahkan kepada tema dan konsep yang terkandung pada objek karya dan peristiwa.Tema merupakan suatu konsep atau dasar pemikiran seorang seniman dalam penciptaan suatu karya.Tahapan ini akan mencoba memahami aspek konteks karya pada batik Mega Mendung yang diciptakan oleh para folk artist di wilayah Cirebon kemudian menganalisis bagianbagian dari karya seni yang mempunyai keterkaitan dengan tipe-tipe pada zaman tersebut, yaitu akan ditelusuri berdasarkan sejarah yang melatari seniman dalam penciptaan karyanya.

Motif Mega Mendung yang terdapat di Cirebon ini adalah motif Mega Mendung klasik. Motif Mega Mendung di keraton Kasepuhan ini telah ada sejak Sunan Gunung Jati menyebarkan agama Islam di wilayah Cirebon pada jaman kesultanan keraton. Batik ini tercipta pada saat Sunan Gunung Jati menyebarkan agama Islam yang berasal dari kaligrafi diolah menjadi batik. Dahulu motif ini hanya digunakan oleh kalangan tertentu saja (oleh raja-raja). Pakaian adat keraton, sebagai pakaian putri keraton atau priayi-priayi keraton, sebagai pakaian untuk penari topeng, upacara tradisi. Biasanya pada jaman dahulu untuk menciptakan suatu motif Mega Mendung mendapat ide yang di adopsi dari keramik-keramik Cina yang dibawa oleh Putri Ong Tien.

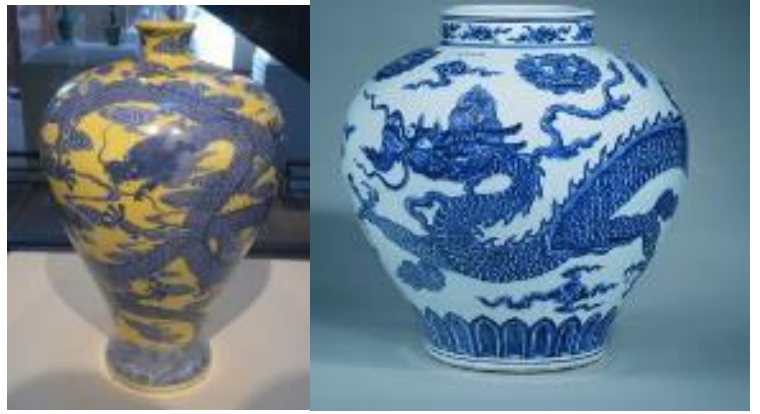

Gambar 2: Keramik-keramik Cina

(Sumber: http://www.indonesian.cri.cn.html, Januari 2016)

Keramik-keramik yang dibawa dari Cina kemudian dikombinasikan dengan kebudayaan khas Cirebon, sehingga menghasilkan perpaduan kabudayaan Cirebon-Cina. Selain keramik-keramik cina tentu saja ditemukannnya simbol-simbol pada Taoisme yang menyerupai motif Mega Mendung. Di negara Cina terdapat beberapa faham Tao mengenai keagamaan yaitu Konfusainisme, Taoisme, dan Buddhisme. Penulis mengambil Taoisme sebagai acuan untuk mempelajari budaya Cina yang masuk ke Cirebon Berikut merupakan benda seni dari Cina yang merupakan benda seni dari Cina yang menggunakan simbol Taoisme.

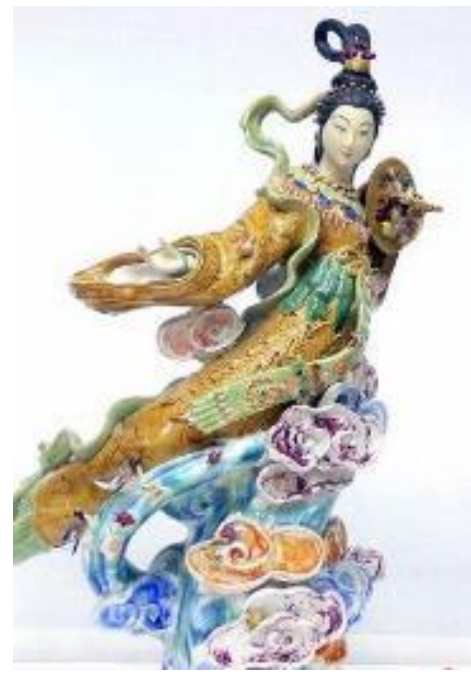

Gambar 3. Lan Ts'ai-ho Terbang di Atas Awan Sumber: http://placedelours.superforum.

Pada benda-benda seni tersebut terlihat motif dan ukiran yang menyerupai Mega Mendung. Bentukbentuk yang menyerupai awan dengan garis spiral diduga merupakan awal mula inpirasi lahirnya motif Mega Mendung. Berikut merupakan simbol dari karakter Cina yang memiliki hubungan dengan motif Mega Mendung 


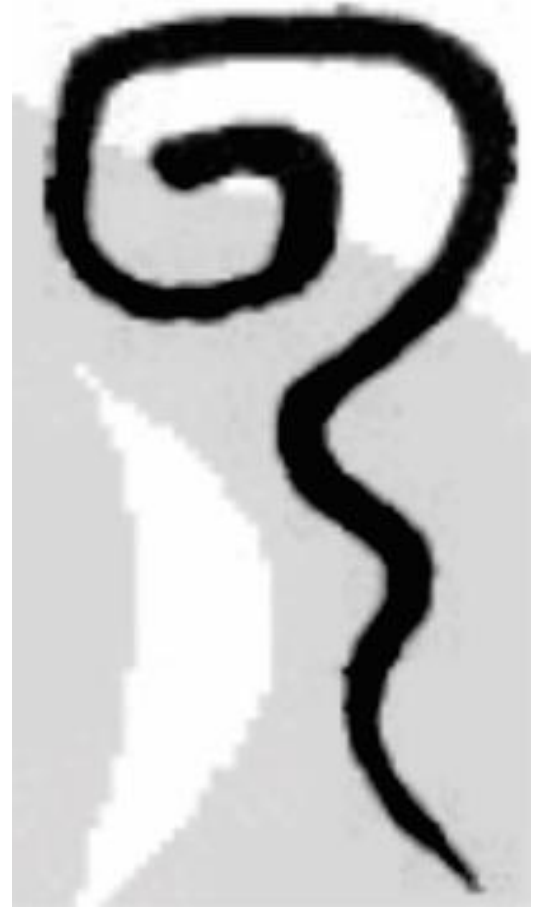

Gambar 4. Yun atau Awan

Sumber: http://placedelours.superforum.

Yun atau awan. Yun merupakan garis lengkung merepresentasikan uap dalam awan. Awan yang tinggi dilangit, dan hujan yang berharga yang tersembunyi di dalamnya, siap untuk jatuh. Artinya jika kita selaras dengan waktu dan tempat yang tepat, maka yang kita butuhkan akan datang dengan sendirinya kepada kita. Awan berkumpul tinggi di atas kepala mereka.

Jika membandingkan dengan simbol-simbol yang terdapat pada Taoisme, terlihat jelas kemiripan motif Mega Mendung dengan simbol awan pada huruf Cina di Taoisme Gambar atau simbol-simbol pada motif Mega Mendung ini terlihat juga pada bangunanbangunan atau ornamen-ornamen yang ada di Keraton Kasepuhan, seperti gambar di bawah ini motif Mega Mendung yang terdapat di atas bangsal keraton Kasepuhan:

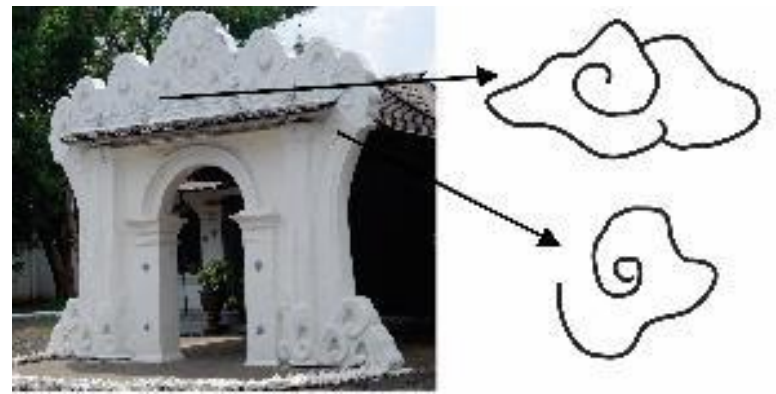

Gambar 5. Bangsal Keraton Kasepuhan Dengan Motif Mega Mendung

Sumber: https://mechtadeera.wordpress.com.

Dengan Perpaduan antara ornamen-ornamen yang ada di Keraton Kasepuhan, dan benda seni yang dibawa dari Cina ini menghasilkan motif Mega Mendung. Para pembatik keraton kemudian menuangkannya kedalam karya batik. Salah satunya adalah motif Mega Mendung. Tentunya dengan sentuhan khas Cirebon, sehingga motif ini tidak sama persis. Pada motif Mega Mendung, garis-garis awan motif Cina berupa bulatan atau lingkaran, sedangkan motif Mega Mendung Cirebon cendrung bentuknya lonjong, lancip, dan berbentuk segitiga. Ini yang membedakan motif awan Cina dengan motif Mega Mendung Cirebon. Menurut Komarudin (2009: 20) mengemukakan bahwa persentuhan budaya Cina dengan seniman batik Cirebon melahirkan motif batik baru khas Cirebon.

Pada proses korektif tahap ini, karya batik Mega Mendung akan dibandingkan dengan karya-karya seniman dari zaman yang sama, seperti yang terlihat pada motif Wadasan. Motif wadasan ini memiliki tema yang sama dengan motif Mega Mendung. Hanya saja motif Wadasan ini adalah istilah Cirebon untuk menyebut motif karang. Adapun istilah untuk menyebut motif karang adalah Gunungan. Primawan (2009: 4) motif gunungan memiliki makna suci yang mengarah pada gambaran kehidupan di alam baka, yaitu sebuah kehidupan yang kekal abadi. Motif wadasan pada kepurbakalaan islam di Cirebon berfungsi sebagai unsure simbolik dan dekoratif.

Fungsi simbolik pada motif ini ditunjukkan oleh letak motif pada bagian utama benda-benda sakral. Motif hias ini terdapat pada taman sari milik keluarga kerajaan yang bagian utamanya berupa bukit-bukit buatan. Dengan demikian motif hias Wadasan sebelum abad ke -18 dapat dikatakan berfungsi sebagai simbol status kebangsawanan. Fungsi dekoratif motif hias wadasan selain sekaligus melekat pada fungsi simboliknya, juga ditunjukkan oleh letak motif tersebut pada bagian pelengkap benda-benda sakral. Dalam konteks benda yang yang ditempati, selain sebagai unsur keindahan, motif hias wadasan juga mempunyai kegunaan lain, yaitu menggambarkan objek yang sesuai dengan konteksnya.

\section{Analisis Tahap Ikonologi Batik Mega Mendung Cirebon}

Motif batik Mega Mendung merupakan hasil dari akulturasi budaya yang lahir dari citra dan karya seniman Cirebon. Motif Mega Mendung dipengaruhi oleh budaya Tiongkok yang masuk ke Cirebon pada abad ke-16 Pengaruh tersebut dapat dilihat pada warna motif Mega Mendung yang berwarna biru dan putih yang diambil dari warna-warna keramik dari Tiongkok yang diberikan Putri Ong Tien kepada Sunan Gunung Jati. Warna motif mega mendung terdiri dari warna biru tua sampai warna biru muda (lihat Gambar 1).

Warna biru tua pada motif mega mendung menggambarkan awan yang mengandung hujan, sedangkan awan yang berwarna biru muda menggambarkan langit yang cerah yang mengisyaratkan kehidupan manusia semakin cerah. Motif Mega Mendung awalnya tidak hanya berwarna 
biru muda dan biru tua saja, tetapi juga memakai warna merah. Hal tesebut dikarenakan proses pembuatan batik di Cirebon tidak hanya dilakukan oleh wanita saja, tetapi laki-laki juga berperan dalam proses pembuatan batik. Warna merah pada batik Mega Mendung menyimbolkan kedinamisan dan kemaskulinitasan pembuatnya. Selain itu warna biru dan merah tersebut juga melambangkan psikologis masyarakat pesisir yang bebas dan terbuka. Garis-garis gambar dari motif Mega Mendung merupakan gambaran perjalanan kehidupan manusia mulai dari lahir, anak-anak, menuju remaja, dewasa, sampai berumah tangga, dan mati. Pada motif mega mendung ini antara lahir tersambung garis yang kesemuanya menyimbolkan kebesaran Tuhan.

Motif Mega Mendung diciptakan sebagai suatu karya seni yang unik, selain itu juga mempunyai filosofi yang mendalam. Adapun filosofi dari motif ini adalah dalam paham Taoisme. Motif ini menggambarkan dunia atas yang luas, dimana di atas langit itu merupakan tempat tinggal para dewa. Sedangkan makna motif batik Mega Mendung dalam ajaran Islam adalah sebagai pembawa hujan yang dinanti-nantikan masyarakat Cirebon. Hujan merupakan sumber kehidupan tanpa adanya hujan manusia tidak bisa hidup.

Dugaan budaya Cina yang mepengaruhi adanya motif tersebut bisa kita coba dikaitkan dengan unsur ketuhanan, karena preseden yang memiliki motif serupa yang merupakn tempat beribadah. Seperti kita lihat pada (gambar 4), pemahaman yang memiliki simbol yang menyerupai motif tersebut, yaitu faham Tao. pada faham Tao yaitu ditemukan simbol yun atau awan. Pada simbol ini terdapat makna yang terkandung di dalamnya, yaitu keberkahan bagi manusia. Manusia hanya perlu menerimnaya pada tempat dan saat yang tepat. Sedangkan motif Mega Mendung pun memiliki makna khusus. Garis melengkung yang tidak terputus melambangkan rejeki atau keberkahan yang tidak ada habisnya. Adanya kemiripan makna ini menguatkan bukti bahwa motif Mega Mendung mengadopsi maknamakna yang terkandung disimbol awan pada faham Tao.

Blumer (1968 : 84-85) mengatakan penggunaan simbol dalam kehidupan sehari-hari digunakan individu untuk dapat memahami maksud antara satu dengan yang lain. Simbol-simbol yang mengandung makna pada motif Mega Mendung ini yang diduga mengambil dari faham Tao. Menurut faham Tao, simbol awan ini memeiliki makna sebagai keberkahan. Tetapi penerapannya pada benda-benda seni Cina yang membawa unsur Taoisme, awan mulai diterapkan sebagai simbol dari dunia atas, tempat tinggal para dewa. Masuknya motif ini kedalam kebudayan Cirebon tidak diterima mentah-mentah melainkan disesuaikan dengan kebudayaan setempat. Motif ini mengalami perubahan bentuk menjadi lancip diujung-ujungnya. Pemahamn ini menunjukkan bahwa motif ini ditempatkan pada tempat-tempat yang bermakna sakral yaitu pada gerbang dan benda pusaka.
Diduga kuat pada penempatan motif ini mengadopsi makna yang diambil dari faham Tao.

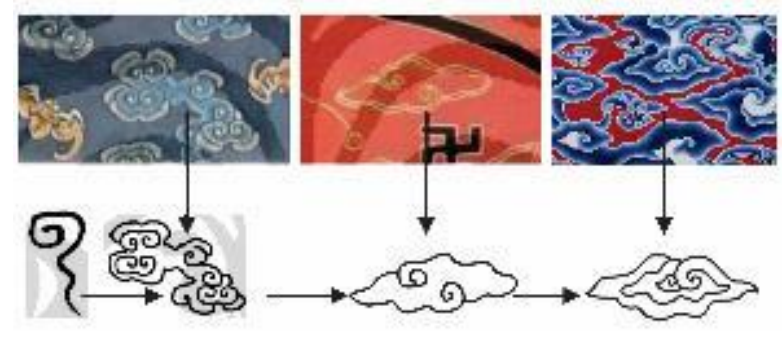

Gambar 6. Perubahan Bentuk Motif dan Simbol Awan Tao Menuju Mega Mendung Sumber: Digambar kembali oleh Irwan Maolana Yusup, Januari 2016

Batik Mega Mendung ini menampilkan awan dengan gaya stilisasi dari perubahan bentuk yang ada pada lambang huruf awan Cina. Proses terbentuknya motif berasal dari garis lengkung dan spiral pada lambang huruf awan di Cina. Motif ini digambarkan berupa kumpuln garis-garis spiral yang menunjukkan bentuk awan. Bentuk tersebut masih digambarkan tidak beraturan untuk setiap awannya. Tetapi motif tersebut tidak berhenti pada bentuk seperti itu. Motif awanawan ini mengalami perkembangan menjadi bentuk satuan yang memanjang horizontal. Motif inilah yang diduga merupakan asal dari lahirtnya motif Mega Mendung.

Interpretasi Ikonologis damat memberikan pengetahuan tentang situasi dan kondisi sejarah motif Mega Mendung yang mengalami perkembangan serta beberapa motif batik sezaman dengan motif batik tersebut, serta dapat pula dilihat kondisi masyarakat di wilayah Cirebon Berawal dari masuknya pedagang asing yang berasal dari Tiongkok, Arab, Persia, dan India yang kemudian menciptakan asimilasi dan akulturasi dari beragam budaya yang menghasilkan banyak tradisi baru bagi masyarakat Cirebon. Pernikahan putri Ong tien dan Sunan Gunung Jati merupakan latar belakang masuknya budaya dan tradisi tiongkok atau tradisi Cina ke keraton. Sedangkan pernak-pernik Cina yang dibawa Ong Tien sebagai persembahan kepada Sunan Gunung Jati, Menjadi inspirasi seniman termasuk pembatik. Maka dapat dilihat pengaruh budaya dari berbagai daerah yang menjadi populer pada zaman itu, serta latar belakang hadirnya kebudayaan, serta berbagai macam gejala dan sejarah yang terjadi yang ditampilkam dalam motif Mega Mendung yang memiliki makna mendalam sebagai hasil interaksi sosial masyarakat.

\section{KESIMPULAN}

Melalui kajian ikonografi bisa diperoleh pemahaman terhadap motif Mega Mendung baik pada aspek tekstual, kontekstual, maupun pemaknaan yang lebih detail dan dalam. Melalui kajian ini, terbukti sangat baik digunakan yang mampu dengan cermat dan dalam mengungkap fakta-fakta sosial dan budaya dari 
suatu zaman dengan penggunaan sumber literatur yang saling berhubungan dan mendukung. Dari analisis primer diperoleh kesimpulan bahwa motif Mega Mendung dikategorikan sebagai gaya stilisasi atau penyerdehanaan bentuk, karya ini mampu memperlihatkan Gaya batik motif Mega Mendung.

Tema dan konsep yang terungkap dalam motif Mega Mendung ini mendapat ide yang diadopsi dari keramik-keramik Cina atau pernak pernik yang dibawa oleh putri Ong Tien. Selain keramik cina juga ditemuknnya simbol Taoisme yang menyerupai motif Mega Mendung. Simbol awan yang menjadi dasar motif Mega Mendung yang menyimbolkan rejeki yang tak ada habisnya, jadi pada intinya motif Mega Mendung yang masuk ke Cirebon mendapat pengaruh dari kebudayaan Cina, yaitu berasal dari simbol-simbol faham Tao. Selain itu nilai-nilai yang terkandung dalam Taoisme pun ikut diadopsi ke dalam makna motif Mega Mendung yang pada akhirnya mempengaruhi letak-letak penempatan motif tersebut.

\section{DAFTAR PUSTAKA}

Case, Lindsey. M. 2019. From Femininity to Feminism: A Visual Analysis of Advertisement Before and After the Femvertising Movement. Elon Journal of Undergraduate Research in Communication, Vo1. 10, No. 1, 35-45. https://www.elon .edu/u/academics/communications/journal/wp content/uploads/sites/153/2019/05/04_Case.p df
Drewniany B.L \& Jewler A. Jerome. 2008. Creative Strategy in Advertising. United States of America : Thomson Wadsworth

Hidayati, Nuril. 2018. Teori Feminisme: Sejarah, Perkembangan \& Relevansinya dengan Kajian Keislaman Kontemporer. Jurnal Harkat : Media Komunikasi Gender, 14 (1), 21-29. http://journal.uinjkt.ac.id/index. php/psga/article/view/10403

Hunt, Alexandra. R. 2017. Selling Empowerment: A Critical Analysis of Femvertising (Senior Communication Honors Thesis). Di akses dari laman http://hdl.handle.net/2345/bc-ir:107483

Kress, G. \& van Leeuwen. T. 2006. Reading Images : the Grammar of Visual Design (second ed), London and New York : Routledge

Kumalanungtyas, Nur \& Sadasri, Lidwina. M. 2018. Citra Tubuh Positif Perempuan dalam Iklan Video Digital (Studi Femvertising pada IKlan Dove Real Beauty). Jurnal Diakom, Vo1. 1 No. 2, 62-73. https://www .neliti.com/publications/278579/citra tu-buhpositif-perempuan-dalam-iklan-video-digital

Olivia, Femi. 2010. Be A Diva: Atraktif (Terapi Kepribadian). Jakarta : PT Elex Media Komputindo

Russel, Thomas. 2013. Commercial Advertising: Six Lecture at The London School of Economic and Political Science. Diakses pada laman https://www.routledge.com/CommercialAdve rtising/Russell/p/book/9781138971158 